\title{
High Commitment Human Resource Management Practices and Employee Outcomes, HR Attribution Theory and a Proposed Model in the Context of Bangladesh
}

\author{
${ }^{*}$ Nadia Newaz Rimi1,2, Yusliza Mohd Yusoff² \\ ${ }^{1}$ University of Dhaka, Bangladesh \\ ${ }^{2}$ Universiti Sains Malaysia, Malaysia \\ *nnrimi@gmail.com
}

\begin{abstract}
Human resource management (HRM) practices have been studied as a composite or bundle approach with different names including different practices. Each bundle includes common HRM practices of staffing, compensation, training and development, performance appraisal, job design and career development issues with varying dimensions. The present study refers these HRM practices as High Commitment HRM (HCHRM) practices. Prior studies identify these HCHRM practices related to employee outcomes of satisfaction, commitment and retention. Consistent with early findings, the present study believes a relation between HCHRM and employee outcomes. Additionally, HR attribution theory is discussed here to explain the causal relationship between HCHRM practices and employee outcomes. Based on the review of HCHRM practices literatures and existing HRM practices of Bangladesh, a research model is proposed and propositions are developed, The model is expected to be tested in future to identify the relationship among HCHRM practices, HR attribution and employee outcomes in the context of Bangladesh. The proposed model can be tested in other countries as well.
\end{abstract}

Keywords: HRM, HCHRM, HR attribution, Employee outcomes, Bangladesh

\section{Introduction}

Contemporary Human Resource Management (HRM) scholars are studying and documenting the developments in HRM in the management literatures (Som, 2007; Schuler \& Jackson, 2008). Most of these developments have seen changes in the nature of the HRM being integrative and value-driven approach (Schuler, 1992; Andersen, Cooper \& Zhu, 2007). Contemporary HRM literatures have highlighted the contribution of HRM to organization performance (alongside other factors) (Subramony, 2009; Caliskan, 2010) and to achieve competitive advantage in organisations (Ashton \& Morton, 2005; Kazlauskaite \& Bučiūniene, 2008). Researchers analyze HRM-performance link and HRM as a source of competitive advantage with a view of HRM as a set or bundle or composite of practices (Huselid, 1995; Delaney \& Huselid 1996). Researchers use different names to refer the bundle or composite HRM practices such as, progressive or 'high performance' (Huselid, 1995; Delaney \& Huselid, 1996), 'high commitment' (Arthur, 1992, 1994; Wood \& de Menezes, 1998), 'high involvement' (Lawler, 1986), or "innovative" (Agarwala, 2003) HRM practices. Coaker (2011) uses the term "HRM Best Practices" referring to what different scholars name HRM set practices as; high performance work practices; high performance work systems; high commitment HRM; best practice HR; and Universal HRM practices. Gould-Williams (2004) find 'high commitment' HRM is widely applied in the UK and 'high performance' HRM is commonly employed in the US. The present study uses the term HCHRM to refer both "HCHRM and HPHRM" interchangeably through identifying the common HRM practices of these two approaches. From prior research review, common HRM practices included in HCHRM and HPHRM are identified. Additionally, HCHRM or HPHRM are found having relation with employee attitudinal and behavioral outcomes such as, commitment and turnover (Arthur 1992, 1994; Huselid 1995) and; job satisfaction (Macky \& Boxall, 2007). Based on these early literature findings, the aim of the present study is developing a research model and propositions regarding the link between HCHRM practices and employee outcomes to be employed in the organizations of Bangladesh. For this purpose, HR attribution theory will be explored to explain the effect of employee attribution to the relationship between HCHRM practices and employee outcomes. The present model is expected to future empirical test within and beyond Bangladesh. 


\section{Literature Review}

HCHRM: Arthur (1992) categories two broad groups of HRM practices and names them based on their uses such as "cost reducers" and "commitment maximizers". According to the author, HRM practices that aim to enhance employee commitment should include decentralized decision making, employee participation, extensive general training and higher wage rates. These HRM practices are better known as commitment focused HRM. In a later research, Arthur (1994) comments that these "commitment maximizers" HRM or HCHRM systems direct desired employee behaviors and attitudes by forming psychological links between organizational and employee goals. Delaney, Lewin, and Ichniowski (1989) as mentioned in Huselid (1995) use a more wider list of "high performance work practices" or HPHRM that includes personnel selection, performance appraisal, incentive compensation, job design, grievance procedures, information sharing, attitude assessment, and labor-management participation in HRM to promote employee performance in the organization. Becker, Huselid, Pickus, and Spratt (1997) include rigorous recruitment and selection, performance-contingent compensation systems, and management development and training activities directed to the needs of the business as part of their "high performance work systems" which are also known as strategic HRM systems. Wood \& de Menezes (1998) characterize High Commitment Management (HCM) by the use of HRM practices including information dissemination, problem-solving groups, minimal status differences, job flexibility and team working in combination. These practices are used as employer's commitment to the employees as assets or resources to be developed for the organization. Guthrie (2001) discusses organization uses high involvement or HCHRM practices when they view HR critical to organizational performance. The value-adding HRM system includes high-involvement work practices of internal promotions, performance- (versus seniority-) based promotions, skill-based pay, group-based (gain sharing, profit-sharing) pay, employee stock ownership, employee participatory programs, information sharing, attitude surveys, teams, cross-training or cross-utilization, and training focused on future skill requirements.

Datta, Guthrie, and Wright (2005) consider HCHRM styles or systems are employee-centered by design. High employee capability coupled with employee commitment and involvement facilitates organization to achieve optimal performance. These systems include practices such as rigorous selection procedures, internal meritbased promotions, grievance procedures, cross-functional and cross-trained teams, high levels of training, information sharing, participatory mechanisms, group-based rewards, and skill-based pay. Lepak, Liao, Chung, and Harden (2006) opine a HCHRM system might rely on policies of selective staffing, comprehensive training, and pay for performance in combination to encourage employee commitment toward the organization and also maximizing their contributions toward organizational performance. Harley, Allen, and Sargent (2007) and Kwon, Bae, and Lawler (2010) view HRM as HCHRM for employee motivation and performance. Wei, Han and Hsu (2010) identify HRM practices as HPHRM practices. HPHR practices or HCHRPs has been treated as a system of a synergistic composition of HRM practices (Guthrie 2001; MacDuffie, 1995; Whitener, 2001; Sun, Aryee, \& Law, 2007). Therefore the present researchers considers five broad categories of HRM practices including rigorous staffing, training and development, equitable and competitive compensation, development oriented performance appraisal, career development and job design to be labelled as HCHRM practices as identified by early researchers.

Empirical Evidences: HCHRM practices can be applied across a variety of industries e.g., automotive assembly plants (MacDuffie, 1995); steel companies and minimills (Arthur, 1992, 1994); not-for profit organizations (Delaney \& Huselid, 1996); high technology firms (Coolins \& Smith, 2006); service organization (Harley et al., 2007). These studies reveal organizations with high commitment systems experience greater productivity, financial performance, and effectiveness than organizations with low commitment or control systems. Furthermore, a number of studies reports the positive impact of a bundle of HCHRM practices on employees' job satisfaction, trust in management motivation, retention and organizational commitment (Agarwala, 2003; Kown et al., 2010; Macky \& Boxall 2007; Pare \& Tremblay, 2007; Ramsay, Scholarios \& Harley, 2000) and the significant moderating role of HCHRM in predicting employees' organizational commitment (Whitener, 2001). Following table (1) summarizes early references of HCHRM practices with their outcomes. 
Table 1: Summary of widely used references for HCHRM practices

\begin{tabular}{|c|c|}
\hline Authors & HCHRM Practices \\
\hline Arthur (1994) & $\begin{array}{l}\text { Employee involvement in managerial } \\
\text { decisions, formal participation programs, } \\
\text { training in group problem solving, and } \\
\text { socializing activities and maintenance of } \\
\text { skilled employees and average wage } \\
\text { rates. }\end{array}$ \\
\hline Huselid (1995) & $\begin{array}{l}\text { Personnel selection, performance } \\
\text { appraisal, incentive compensation, job } \\
\text { design, grievance procedures, } \\
\text { information sharing, attitude assessment, } \\
\text { labor-management participation in } \\
\text { human resource management, the } \\
\text { intensity of recruiting efforts (selection } \\
\text { ratio), the average number of hours of } \\
\text { training per employee per year, and } \\
\text { promotion criteria (seniority versus } \\
\text { merit) }\end{array}$ \\
\hline Whitener (2001) & $\begin{array}{l}\text { Selective staffing, comprehensive } \\
\text { training, developmental appraisal, } \\
\text { externally, and internally equitable } \\
\text { reward systems. }\end{array}$ \\
\hline
\end{tabular}

Agarwala (2003) Employee acquisition, retention, compensation and incentives, Benefits and services, Rewards and recognition, Technical training, Management development, Career planning and development practices, Performance appraisals, Potential development, Succession planning, Employee relations with a human face, Employee exit and separation management, Adopting responsibility for socially relevant issues.

Gould-Williams Team working, employee involvement, (2004) empowerment, the offer of fair rewards, training and job security.

Harley et al. (2007) Autonomous team membership, rigorous selection, performance appraisal, performance feedback, performance linked to outcomes, competitive pay, pay linked to performance, training, consultation, say in decisions,

Kown et al. (2010) Job design, participation in decision making, training and development, pay for performance, high level of pay and performance appraisal.

Chiang, Han, and Selective staffing, comprehensive Chuang (2011) training and development, developmental appraisal, as well as competitive and equitable compensation.

\section{Findings}

High commitment systems have higher productivity, lower scrap rates, and lower employee turnover.

HPWPs reduce turnover, increase productivity and thereby enhance firm's financial performance.

HCHRM practices moderate the relationship between perceived organizational supports and employee commitment to the organization.

The innovative HR practices are the most significant predictors of organizational commitment.

HCHRM influences employee satisfaction, motivation, commitment and intention to quit in the public sector organizations.

HPWS have more positive outcomes for low-skilled than high-skilled workers in service organization.

HCHRM practices are positively related to the affective organizational commitment of top performers more than that of lower performers.

HCHRM practices dominate knowledge-sharing behavior via perceived organizational support (POS) and organizational commitment. 
Wei et al. (2010)

Sun et al. (2007)
High-performance HR practices include offering internal career opportunities, extensive training, employment security, participation and communication, sensitive selection, and incentive compensation,

Selective staffing, extensive training, internal mobility, employment security, broad job design, results-oriented appraisal, rewards, and participation.
HPHRPs explain psychological climate. Job satisfaction mediates the relationship between psychological climate perceptions and organizational citizenship behavior (OCB) at the individual level. At the plant level, HPHR practices have a positive and significant relationship only with job satisfaction.

Service-oriented OCB partially mediates the relationship between HPHRPs and both performance indicators of turnover and productivity.

HRM in Bangladesh: Examining the organization of HRM within the Government of Bangladesh, Siddiquee (2003) highlights the current flaws of and future challenges to HRM in Bangladesh civil services. Current HRM deficiencies combined with bureaucratic corruption and increasing incidence of politicization adversely affect quality and performance of civil services. Ehsan (2008) discusses the challenges of the structural and management aspects of public sector HRM (PHRM) of Bangladesh. Based on theoretical perspective and associated themes derived from the United Nations Department of Economic and Social Affairs' (UN/DESA) WPSR (World Public Sector Report) 2005 titled Unlocking the Human Potential for Public Sector Performance, Ehsan develops a model for PHRM with a broad ranges of recommendations in upgrading PHRM system. Bangladeshi private sector organizations are not matured enough at the stage of their development (Absar, Nimalathasan \&, Mahmood, 2012). At this condition, the importance of HRM as well as role of HR department in the private organizations is still not very visible (Mahmood \& Akhter, 2011). However, as the country is experiencing gradual economic development with more FDI inclusion and business growth, Bangladeshi managers need to be prepared to adopt systematic HRM to acquire, motivate and retain employees (Absar et al., 2012). Local researchers suggest improving different aspects of HRM that will have expected effect on employee attitude namely, job satisfaction, commitment, retention, turnover intention and morale of HR of private commercial banks (Billah \& Islam, 2009; Islam, Mohajan, \& Datta, 2012; Rahman \& Iqbal, 2013; Newaz, Ali, \& Akhter, 2007); Islamic banks (Rahman \& Shahid, 2009); pharmaceutical company (Ahmed, Tabassum \& Hossain, 2006); private university (Joarder \& Sharif, 2011); and Ready Made Garment industry (Hossan, Sarker \& Afroze, 2012). The following table (2) summarizes research works on HRM practices in the organizations of Bangladesh.

Table 2: Summary of studies on HRM practices of Bangladesh

\begin{tabular}{|c|c|c|}
\hline Authors & HRM Practices & Findings \\
\hline Siddiquee (2003) & $\begin{array}{l}\text { HR planning, staffing policy, promotion } \\
\text { and transfer policy, performance } \\
\text { appraisal system and reward structure of } \\
\text { Government organizations. }\end{array}$ & $\begin{array}{l}\text { Existing HRM practices suffer from } \\
\text { serious lack in promoting employee } \\
\text { performance and in getting merit, } \\
\text { professionalism and integrity in the } \\
\text { public service in future. }\end{array}$ \\
\hline Ehsan (2008) & $\begin{array}{l}\text { Public sector HRM practices of } \\
\text { recruitment policy, pay scale, }\end{array}$ & $\begin{array}{l}\text { Inappropriate HRM practices to } \\
\text { promote public administration services. }\end{array}$ \\
\hline
\end{tabular}
performance appraisal system, career management issues, and performancebased promotion policy.

Ahmed et al. HR planning, recruitment and selection, (2006) induction, training, performance appraisal, employee development, compensation plan of Pharmaceutical company.

Joarder and Sharif Compensation, supervisory support, job

HRM practices are not capable to give competitive advantage to the organization.

HRM practices significantly influence 
(2011)

Islam et al. (2012)

Rahman and Iqbal (2013)

Newaz et al. (2007)

Rahman

Shahid (2009)

Zaman (2011)

Hossan

(2012) security of Private University.

Pay, Decision making authority, Promotional policy of PCBs.

Job security, professional development, promotional opportunity, working autonomy, working environment, compensation package, and financial benefits of PCBs.

Job design, job recognition, pay and benefits, training opportunity, career development of PCBs.

performance appraisal, compensation system, selection and recruitment of Islami Shariah based PCBs.

Recruitment process of hospital

al. Wages and overtime payment, performance appraisal, job security, bonus system of RMG industry. faculty turnover intention.

HRM practices are significantly related with bank employees' job satisfaction and morale.

HRM practices determine employee job satisfaction and turnover.

HRM practices are related with employee turnover.

Except recruitment, all other HRM practices affect organizational commitment of employees.

Dissatisfactory recruitment policy and practice in hospitals of Bangladesh.

HRM practices cannot improve employee performance of labour intensive manufacturing organization.

HR Attribution Theory: Research study shows that HRM practices are associated with organizational performance through their influences on employee attitude and behavior (Colakoglu, Lepak \& Hong, 2006; Azmi, 2011) and employee perceptions of HRM (Allen, Shore \& Griffeth, 2003; Bowen \& Ostroff, 2004). Based on this suggestion, Nishii, Lepak and Schneider (2008) construct HR attributions theory. The theme of the HR attribution says the attributions that employees develop about the intentions of management adopting particular HR practices have consequences for their individual attitudes and behaviors, and ultimately, unit performance. Nishii et al (2008) examine five main HRM practices including staffing, training, benefits, pay, and performance appraisals and identify employees attribute these HRM practices to (1) enhance (service) quality; (2) keep costs down; (3) promote employee well-being; (4) get the most work out of them; and (5) comply with union requirements. Employee attribution to HRM practices as management intention to promote employee service quality and well-being is positively related to HRM practices and employee attitude and behavior relationship. On the other hand, employee attribution to HRM practices as management policies to minimize costs and to exploit employees is negatively related to HRM practices and employee attitude and behavior relationship. However, employee attribution to HRM practices as management conformity to the pressure of union is not significantly related to their attitude and behavior. Nishii et al (2008) confirm their assumptions by testing the theory in a service organization. The authors find that employees have developed varying attributions for the same HRM practices and that these attributions generate different level of employee commitment and satisfaction. In turn, individual attribution is shared within units and consequently it affects unit-level OCB and customer satisfaction.

Research gap: In HR attribution theory, Nishii et al. (2008) refer HR attributions to "employees' causal explanations for HR practices to which they are exposed on an ongoing basis". Here the proponents discuss how HRM practices influence HRM outcomes on employees via employees' attribution to management intention to use specific HRM practices. Based on the HR attribution theory, the present researchers believe that HCHRM practices can enhance employee commitment, satisfaction and retention if employees attribute HCHRM practices promoting their service or performance quality and well-being. The present model aims to explore the HR attribution effect on HCHRM-employee outcomes (satisfaction, motivation, retention) relationship as fulfilling the gap of studying HCHRM-HR attribution-HR outcome relationship.

\section{Proposed Research Model}

The present researcher proposes a research model on HCHRM practices to be tested in the organizations of Bangladesh. HCHRM practices are identified based on HCHRM literature study. These HCHRM practices are also found related with existing HRM practices of Bangladeshi organizations. The model explains that 
organization should introduce HCHRM practices (rigorous staffing, training and development, development oriented performance appraisal, competitive and equitable compensation, career development and job design) that will increase employee performance quality and well-being which in turn will enhance employee satisfaction, commitment and retention. Here emphasis is given on understanding employee perceptions in improving, developing and implementing HCHRM practices to generate positive employee outcomes. Figure (1) shows the proposed HCHRM model. The following table (3) summarizes HCHRM practices with early references.

\section{Figure 1: Proposed HCHRM model}

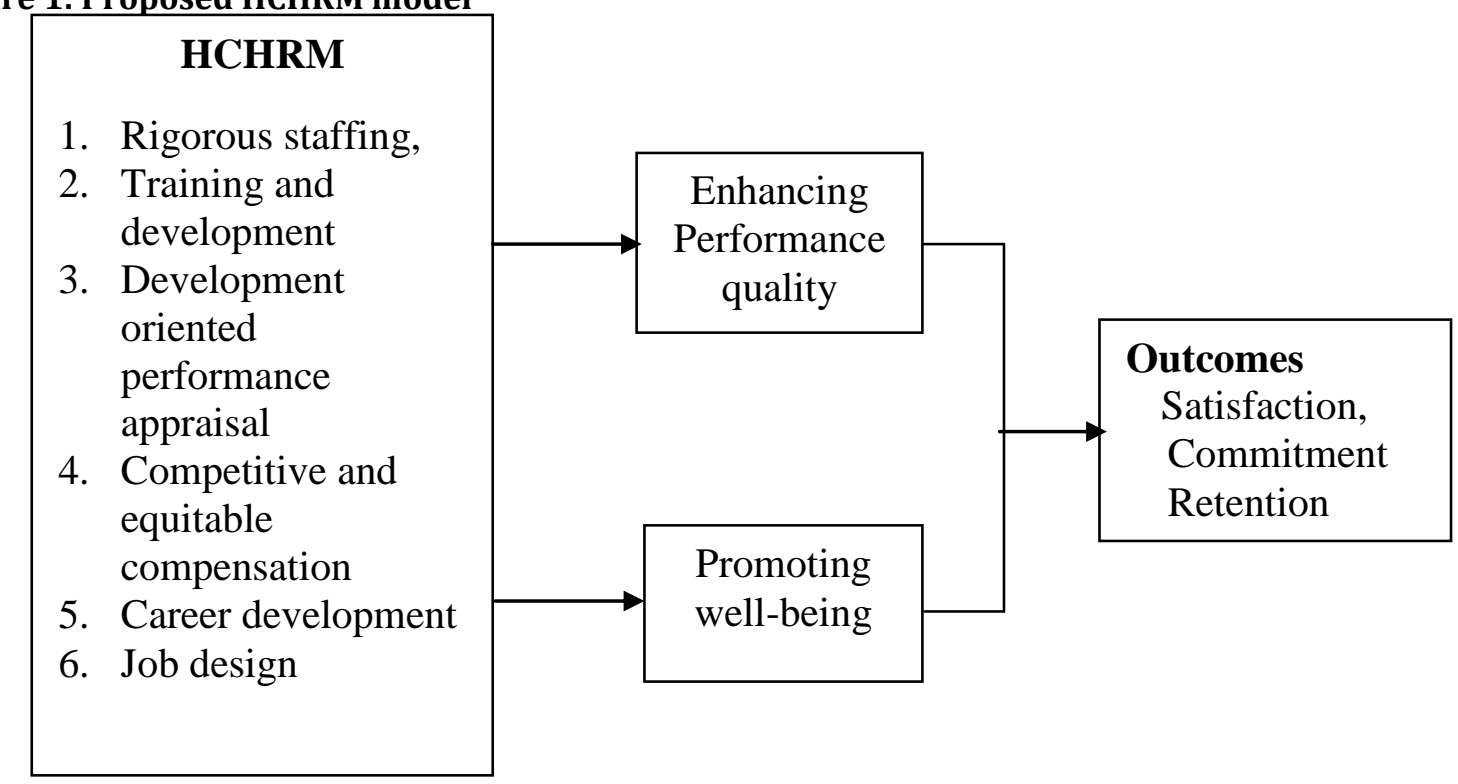

Table 3: Summary of different HRM practices included in the present HCHRM model

\begin{tabular}{ll}
\hline HCHRM practices & References \\
\hline Staffing & Huselid, (1995); Whitener, (2001); Agarwala (2003); Chiang et \\
& al. (2011). \\
Training and development & Huselid, (1995); Whitener, (2001); Harley et al. (2007); Kown et \\
& al. (2010); Chiang et al. (2011). \\
Performance Appraisal & Huselid, (1995); Whitener, (2001); Agarwala (2003); Harley et al. \\
& (2007); Kown et al. (2010) Chiang et al. (2011). \\
Competitive and $\quad$ equitable & Huselid, (1995); Whitener, (2001); Harley et al. (2007); Chiang et \\
compensation & al. (2011). \\
Career Development & Agarwala (2003); Wei et al. (2010). \\
Job Design & Kown et al. (2010); Sun et al. (2007). \\
\hline
\end{tabular}

Propositions: Following propositions can be developed from the proposed research model:

Proposition 1: Employee perceived HCHRM as performance quality enhancing is positively related to employee job satisfaction, commitment and retention.

Proposition 2: Employee perceived HCHRM as well-being promoting is positively related to employee job satisfaction, commitment and retention.

\section{Conclusion}

In this paper, an overview of HCHRM practices with their effects on the organization is accumulated. HRM practices of the organizations across different industries of Bangladesh are also presented. HR attributions theory is discussed to relate HCHRM practices with employee outcomes. Based on the literatures on HCHRM and HRM practices of Bangladeshi organizations, this paper has proposed a set of HCHRM practices including rigorous staffing, training and development, performance appraisal for development, competitive and 
equitable compensation, career development and job design. These HCHRM practices will most significantly influence satisfaction, commitment and retention of employees with an understanding of positive employee attribution of HCHRM as performance quality enhancing and well-being promoting. Such relationship is shown in a research model to be applied in the organizations of Bangladesh. Thus, well-designed empirical studies to be conducted to test the relationships offered in this model are sought. In this respect, more research can be conducted to explore HCHRM-HR attribution theory-HR outcomes relationship considering country context HRM practices that will validate the proposed model globally.

Acknowledgments: The funding for this study was supported in part by an Incentive Postgraduate Research Grant (1001/PMGT/822209) from Universiti Sains Malaysia.

\section{References}

Absar, N., Nimalathasan, B. \& Mahmood, M. (2012). HRM-market performance relationship: evidence from Bangladeshi organizations. South Asian Journal of Global Business Research, 1(2), 238-255.

Agarwala, T. (2003). Innovative human resource practices and organizational commitment: an empirical investigation. International Journal of Human Resource Management, 14(2), 175-197.

Ahmed, J. U., Tabassum, A. \& Hossain, T. (2006). Human resource management practices: a case study of the supply chain department of square pharmaceuticals Ltd. Sri Lankan Journal of Management, 11(1), 89-107.

Allen, D. G., Shore, L. M. \& Griffeth, R. W. (2003). The role of perceived organizational support and supportive human resource practices in the turnover process. Journal of Management, 29(1), 99-118.

Andersen, K. K., Cooper, B. K. \& Zhu, C. J. (2007). The effect of SHRM practices on perceived firm financial performance: Some initial evidence from Australia. Asia Pacific Journal of Human Resources, 45(2), 168-179.

Arthur, J. B. (1992). The link between business strategy and industrial relations systems in American steel minimills. Industrial and Labor Relations Review, 45(3), 488-506.

Arthur, J. B. (1994). Effects of human resource systems on manufacturing performance and turnover. Academy of Management journal, 37(3), 670-687.

Ashton, C. \& Morton, L. (2005). Managing talent for competitive advantage: Taking a systemic approach to talent management. Strategic HR Review, 4(5), 28-31.

Azmi, F. T. (2011). Strategic human resource management and its linkage with HRM effectiveness and organizational performance: evidence from India. The International Journal of Human Resource Management, 22(18), 3888-3912.

Becker, B. E., Huselid, M. A., Pickus, P. S. \& Spratt, M. F. (1997). HR as a source of shareholder value: research and recommendations. Human resource management, 36(1), 39-47.

Billah, M. \& Islam, S. (2009). Human resource management practices and organizational commitment: a survey on private commercial banks in Bangladesh. Southeast University journal of Business Studies, 5(1), 153-166.

Bowen, D. E. \& Ostroff, C. (2004). Understanding HRM-firm performance linkages: the role of the strength of the HRM system. Academy of management Review, 29(2), 203-221.

Caliskan, E. N. (2010). The impact of strategic human resource management on organizational performance. Journal of Naval science and engineering, 6(2), 100-116.

Chiang, H. H., Han, T. S. \& Chuang, J. S. (2011). The relationship between high-commitment HRM and knowledge-sharing behavior and its mediators. International Journal of Manpower, 32(5/6), 604-622.

Coaker, S. (2011). Exploring the value and application of HRM best practice theory within a third sector micro-organization (pp. 1-35): University of Hertfordshire Business School Working Paper.

Colakoglu, S., Lepak, D. P. \& Hong, Y. (2006). Measuring HRM effectiveness: considering multiple stakeholders in a global context. Human Resource Management Review, 16(2), 209-218.

Collins, C. J. \& Smith, K. G. (2006). Knowledge exchange and combination: The role of human resource practices in the performance of high-technology firms. Academy of Management Journal, 49(3), 544560.

Datta, D. K., Guthrie, J. P. \& Wright, P. M. (2005). Human resource management and labor productivity: does industry matter? Academy of Management Journal, 48(1), 135-145. 
Delaney, J. T. \& Huselid, M. A. (1996). The impact of human resource management practices on perceptions of organizational performance. Academy of Management Journal, 39(4), 949-969.

Ehsan, M. (2008). Public sector human resource management in Bangladesh: challenges and opportunities in light of the WPSR 2005. Asian Affairs, 30(4), 50-75.

Gould-Williams, J. (2004). The effects of 'high commitment' HRM practices on employee attitude: the views of public sector workers. Public Administration, 82(1), 63-81.

Guthrie, J. P. (2001). High-involvement work practices, turnover, and productivity: Evidence from New Zealand. Academy of Management Journal, 44(1), 180-190.

Harley, B., Allen, B. C. \& Sargent, L. D. (2007). High performance work systems and employee experience of work in the service sector: the case of aged care. British Journal of Industrial Relations, 45(3), 607633.

Hossan, C. G., Sarker, M. A. R. \& Afroze, R. (2012). Recent Unrest in the RMG Sector of Bangladesh: Is this an Outcome of Poor Labour Practices? International Journal of Business and Management, 7(3), 206-218.

Huselid, M. A. (1995). The impact of human resource management practices on turnover, productivity, and corporate financial performance. Academy of Management Journal, 38(3), 635-672.

Islam, J. l. N., Mohajan, H. K. \& Datta, R. (2012). A study on job satisfaction and morale of commercial banks in Bangladesh. Int. J. Eco. Res, 153, 153-173.

Joarder, M. H., Sharif, M. Y. \& Ahmmed, K. (2011). Mediating role of affective commitment in HRM practices and turnover intention relationship: A study in a developing context. Business and Economics Research Journal, 2(4), 135-158.

Kazlauskaite, R. \& Buciuniene, I. (2008). The role of human resources and their management in the establishment of sustainable competitive advantage. Inzinerine Ekonomika-Engineering Economics, 5, 78-84.

Kwon, Bae, J. \& Lawler, J. J. (2010). High commitment HR practices and top performers. Management International Review, 50(1), 57-80.

Lawler, E. E. (1986). High-Involvement management. Participative strategies for improving organizational performance: ERIC.

Lepak, D. P., Liao, H., Chung, Y. \& Harden, E. E. (2006). A conceptual review of human resource management systems in strategic human resource management research. Research in Personnel and Human Resources Management, 25, 217-271.

MacDuffie, J. P. (1995). Human resource bundles and manufacturing performance: Organizational logic and flexible production systems in the world auto industry. Industrial and Labor Relations Review, 48(2), 197-221.

Macky, K. \& Boxall, P. (2007). The relationship between 'high-performance work practices' and employee attitudes: an investigation of additive and interaction effects. The International Journal of Human Resource Management, 18(4), 537-567.

Mahmood, M. \& Akhter, S. (2011). Training and development in Bangladesh. International Journal of Training and Development, 15(4), 306-321.

Newaz, M. K., Ali, T. \& Akhter, I. (2007). Employee perception regarding turnover decision- in context of Bangladesh banking Sector. BRAC University Journal, 4(2), 67- 74.

Nishii, L. H., Lepak, D. P. \& Schneider, B. (2008). Employee attributions of the why of HR practices: Their effects on employee attitudes and behaviors, and customer satisfaction. Personnel Psychology, 61(3), 503-545.

Paré, G. \& Tremblay, M. (2007). The influence of high-involvement human resources practices, procedural justice, organizational commitment, and citizenship behaviors on information technology professionals' turnover intentions. Group \& Organization Management, 32(3), 326-357.

Rahman, M. M. \& Iqbal, M. F. (2013). A comprehensive relationship between job satisfaction and turnover intention of private commercial bank employees' in Bangladesh. International Journal of Science and Research, 2(6), 17-23.

Rahman, N. M. N. A. \& Shahid, S. (2009). Islamic HRM practices and employee commitment? A test among employees of Islamic banks in Bangladesh. Graduate School of Business, Universiti Kebangsaan Malaysia.

Ramsay, H., Scholarios, D. \& Harley, B. (2000). Employees and High-Performance Work Systems: Testing inside the Black Box. British Journal of Industrial Relations, 38(4), 501-531. 
Schuler, R. S. (1992). Strategic human resources management: linking the people with the strategic needs of the business. Organizational Dynamics, 21(1), 18-32.

Schuler, R. S. \& Jackson, S. E. (2008). A quarter-century review of human resource management in the US: The growth in importance of the international perspective. Strategic Human Resource Management, 16(1), 11-35.

Siddiquee, N. A. (2003). Human resource management in Bangladesh civil service: Constraints and contradictions. International Journal of Public Administration, 26(1), 35-60.

Som, A. (2007). What drives adoption of innovative SHRM practices in Indian organizations? The International Journal of Human Resource Management, 18(5), 808-828.

Subramony, M. (2009). A meta-analytic investigation of the relationship between HRM bundles and firm performance. Human Resource Management, 48(5), 745-768.

Sun, L. Y., Aryee, S. \& Law, K. S. (2007). High-performance human resource practices, citizenship behavior, and organizational performance: a relational perspective. Academy of Management Journal, 50(3), 558-577.

Wei, Y. C., Han, T. S. \& Hsu, I. C. (2010). High-performance HR practices and OCB: a cross-level investigation of a causal path. The International Journal of Human Resource Management, 21(10), 1631-1648.

Whitener, E. M. (2001). Do high commitment human resource practices affect employee commitment? A cross-level analysis using hierarchical linear modelling. Journal of Management, 27(5), 515-535.

Wood, S. \& De Menezes, L. (1998). High commitment management in the UK: evidence from the workplace industrial relations survey, and employers' manpower and skills practices survey. Human Relations, 51(4), 485-515.

Zaman, L. (2011). Human resource management (HRM) in hospitals: a research on the recruitment process of a Bangladeshi hospital. Asia Pacific Journal of Research in Business Management, 2(9), 93-98. 